\title{
Changes in European eel ovary development and body and ovary chemistry during stimulated maturation under controlled conditions: preliminary data
}

\author{
Joanna Nowosad • Dariusz Kucharczyk • Joanna Luczyńska • \\ Katarzyna Targońska • Tomasz Kajetan Czarkowski • Maria Biłas • \\ Sławomir Krejszeff • László Horváth • Tamás Müller
}

Received: 15 January 2014/Accepted: 8 May 2014/Published online: 30 May 2014

(C) The Author(s) 2014. This article is published with open access at Springerlink.com

\begin{abstract}
This study compared changes in the biochemical composition of muscles and ovaries of maturing female European eels during hormonal stimulation with carp pituitary homogenate under controlled conditions and in the development of oocytes. It has been found that differentiation of oocyte size in eel is visible from the beginning of the gamete maturation process. This differentiation increases as gonads grow. Furthermore, oocytes are at different development stages and are still highly differentiated in terms of size during ovulation. Moreover, the biochemical composition of the body and gonads was found to change. During the process of maturation, the relative fat content in the eel body decreases both in the muscles (from $21.99 \pm 4.3$ to $18.48 \pm 3.3 \%$ ) and in gonads (from $25.76 \pm 2.71$ to $15.21 \pm 4.7 \%$ ), with the changes in ovaries being more rapid. Protein content in muscles also decreased (from $15.98 \pm 3.13$ to $12.35 \pm 1.6 \%$ ) during the process of female maturation. Different trends were observed for polyunsaturated fatty acids (EPA and DHA). The total amount of these acids decreased in muscles $(P<0.05)$ but increased in ovaries $(P>0.05)$.
\end{abstract}

Keywords European eel $\cdot$ Fat $\cdot$ Maturation $\cdot$ Oocyte diameter $\cdot$ Protein

\footnotetext{
J. Nowosad $(\bowtie) \cdot$ D. Kucharczyk $\cdot$ K. Targońska $\cdot$ M. Biłas $\cdot$ S. Krejszeff Department of Lake and River Fisheries, University of Warmia and Mazury in Olsztyn, Al. Warszawska 117A, 10-957 Olsztyn, Poland

e-mail: nowosad.joanna@gmail.com

J. Łuczyńska

Department of Commodity Science and Food Analysis, University of Warmia and Mazury in Olsztyn, Olsztyn, Poland

T. K. Czarkowski

Warmia and Mazury Centre for Agricultural Consulting, Olsztyn, Poland

L. Horváth · T. Müller

Department of Fish Culture, Szent István University, Páter K. u. 1, Gödöllő 2100, Hungary
} 


\section{Introduction}

The population of the European eel (Anguilla anguilla) has decreased dramatically over the past three decades. It is estimated that it has dropped to a mere $1 \%$ of its 1970 levels (Dekker 2003; Bevacqua et al. 2011). Currently, the species is outside the limits of biological safety and, consequently, it has been placed on the Red List of endangered species in Europe (Belpaire et al. 2009; Prigge et al. 2012). Such radical changes in the eel population have been attributed, inter alia, to excessive exploitation of the species, deterioration of the environment, climatic changes and infestation of the swimming bladder with the Anguillicoloides crassus nematode (e.g., Friedland et al. 2007; Belpaire et al. 2009; Clevestam et al. 2011). Intensive research to develop an artificial reproduction technique for this species (Palstra et al. 2005), as well as stocking actions aimed at increasing its population in the waters of Europe (Vogel 2010) is among the measures taken to save the European eel from total extinction.

The eel is a species with an interesting life story-it spends most of its life in European fresh water, but it swims to spawn in the Sargasso Sea area, covering thousands of kilometers during its spawning migration. Many intensive physiological and morphological changes take place in the eels during the maturation process (Müller et al. 2004a; b; van Ginneken et al. 2005a; Clevestam et al. 2011; Nowosad et al. 2014). Although the European eel is regarded as a trophic opportunist (Prigge et al. 2012), it does not consume any food during its migration journey and it takes the energy it needs to travel the thousands of kilometers and undergo the maturation process from the fat accumulated in its body (Clevestam et al. 2011). Proper sexual maturation - vitellogenesis and ovary development brought about by environmental factors - takes place during the migration journey (Duriff et al. 2006). The decreased deposits of fatty tissue (as observed recently in juvenile fish in inland waters) can have consequences for older individuals, by preventing silver state females from reaching spawning grounds and ovaries from maturing properly. In some cases, the accumulated energy may even be insufficient for reaching the spawning ground (Clevestam et al. 2011), which makes the situation even more difficult for the species.

Despite researchers' considerable interest in the species, there is still only scarce information on the basic biological processes of changes in the bodies of European eel brooders which take place during its spawning migration. It could be said that information about climate fluctuations is more easily available than on the European eel, to be precise - on the changes which occur during its long journey to the spawning ground, maturation and fasting. What changes take place in their muscles? What about gonads? These questions have inspired researchers to study this species in more detail.

The aim of this study was to compare changes in the biochemical composition of muscles and gonads of maturing female European eels and the development of ovaries with and without hormonal stimulation with carp pituitary homogenate $(\mathrm{CPH})$ under controlled conditions.

\section{Materials and methods}

Fish

Eel brooders (42 female fish) were caught during commercial fishing activities in freshwater in the Mazury region (the northeast of Poland) as fish which start their spawn migration (at the end of May). The collection of fish was made during few following days. 
After being caught, the fish were transported to the laboratory of the Department of Lake and River fisheries, University of Warmia and Mazury, Olsztyn, where they were put into a $1-\mathrm{m}^{3}$ tank, operating in closed water circulation (Kujawa et al. 1999). The initial water temperature was $12{ }^{\circ} \mathrm{C}\left( \pm 0.2{ }^{\circ} \mathrm{C}\right)$. The photoperiod applied was natural and photocellcontrolled. The oxygen level in the water was at least $6 \mathrm{ppm}$. The fish stayed about 1 month in the freshwater tank until the start of the experiment.

Handling the fish

All the fish handling was conducted in the state of anesthesia (MS-222 (300 ppt), Finquel, USA). After being anesthetized, the fish were measured (TL, eye diameter), weighed and labelled with individual PIT labels (Biomark, USA). The fish handling was conducted in a slightly dimmed room. The fish (with a mean body weight (BW) of 1,174.9 $\pm 250.0 \mathrm{~g}$ and the mean length (LT) of $86.2 \pm 5.6 \mathrm{~cm}$ ) were divided into two groups: C, control group, no hormonal stimulation $(n=14)$ and the experimental group $\mathrm{T}, n=28$. Samples (minimum 5 fish each) were taken from group T in week 2-4-group TI, and in week 13-15 of the experiment-group TII. Subsequently, fish from groups C and T were transferred to $1-\mathrm{m}^{3}$ tanks operating in closed water circulation. The circulation had controllable physico-chemical conditions (temperature, photoperiod), and the system was also equipped with a polygeser filter and UV lamps $(2 \times 36 \mathrm{~W}$ each). The initial water temperature was set at $12{ }^{\circ} \mathrm{C}$, and the photoperiod was $0 \mathrm{~L}: 24 \mathrm{D}$. Subsequently, the water was salted (Aqua Nova, Australia) over 7 days to the level of 33-35\%. After 20 days, the water was heated to the level of $15^{\circ} \mathrm{C}\left( \pm 0.1^{\circ} \mathrm{C}\right)$. The fish were not fed throughout the experiment.

\section{Hormonal stimulation}

The hormonal stimulation was started after the desired water salinity level was achieved using the method described by Nowosad et al. (2014). After being taken out of the tanks, the fish were put in a container with an anesthetic. After being anesthetized, the fish were weighed and had their eye diameter measured. Subsequently, fish from experimental groups were interperitoneally injected at $18 \mathrm{mg} \mathrm{kg}^{-1}$ of carp pituitary homogenate $(\mathrm{CPH}$, Agrent, USA). The hormones were not given to the fish in the control group. The fish handling was conducted at 5-day intervals, for 15 weeks. Using obtained measurements, the body weight index (BWI) was calculated as follows: $\mathrm{BWI}=$ actual body weight $\times 100 \%$ /initial body weight.

\section{Sampling}

Before the samples were taken, fish were anesthetized until their life functions stopped. Ovaries and a fragment of a muscle from the middle (the same) section of a female body were taken for biochemical analyses. Fish were taken for analyses [gonadosomatic index (GSI), chemical composition of muscles and gonads, oocytes development] randomly at the start of the experiment, during its initial period (day 15-30)_-group TI and during its final period (day 90-115) - group TII. Samples for analyses were taken from the control group at the beginning and at the end of the experiment. The gonadosomatic index was calculated from the formula: $\mathrm{GSI}=\left(\mathrm{GW} \mathrm{BW}^{-1}\right) 100 \%$, where $\mathrm{GW}$ : gonad weight $(\mathrm{g})$, BW: body weight $(\mathrm{g})$. 
Histological analysis

The gonads were weighed with an accuracy of $\pm 0.01 \mathrm{mg}$, and subsequently approximately $1-\mathrm{cm}^{3}$ fragments were removed for histological examinations, placed into glass containers and fixed in Bouin's fluid. Depending on the size and amount of the material taken for the analysis, the fixing time ranged from 2 to 3 days. The fixed material was put into biopsy cartridges and then into a tissue processor (LEICA TD 1020) for $21 \mathrm{~h}$, where it was washed in ethanol at increasing concentrations $(75,80,90,95 \%)$, acetone, xylene and liquid paraffin at $54{ }^{\circ} \mathrm{C}$. The obtained study material was then sealed in paraffin blocks and sliced in a rotating microtome (LEICA RM 2155) into 0.5-0.7- $\mu \mathrm{m}$ thick sequences. The paraffin sections were put onto protein-covered slides. The preparations were made with Mayer's hemotoxin and eosin (H + E method) (Bagiński 1965). Subsequently, the stained preparations were sealed with cover slips and histokitt (Glaswarenfabrik Karl Hecht GmbH \& Co KG, Germany). After drying, the histological preparations were analyzed under an optical microscope (Axio Scope A1, Zeiss, Germany) with AxioVs40 v 4.8. 2.0 software (Carl Zeiss MicroImaging GmbH, Germany).

Analysis of chemical composition of muscles and gonads

The chemical composition of gonads and muscles was analyzed. The analyzed features included the content of dry matter, protein, ash, fat and fatty acid profiles.

Dry weight: Approximately 1-g samples $( \pm 0.0001 \mathrm{~g})$ in duplicate were initially dried at $65-70{ }^{\circ} \mathrm{C}$ in quartz tests, then dried to a constant weight at $105{ }^{\circ} \mathrm{C}$ for $1 \mathrm{~h}$.

Protein: The protein content was determined following the method of Kjeldahl according to PN-75 A-04018.

Ash: The samples (about $1 \pm 0.0001 \mathrm{~g}$ ) were dry-digested at $680{ }^{\circ} \mathrm{C}$ for $6 \mathrm{~h}$ in quartz tests.

Fat: The fat content was determined using the Schmidt-Bondzynski-Ratzlaff C method (Berg and Nilsson 1997). To this end, approximately 2-g $( \pm 0.0001 \mathrm{~g})$ samples were hydrolyzed in $8 \mathrm{M} \mathrm{HCl}$ and transferred to a 100-ml cylinder. $10 \mathrm{ml}$ of $95 \%$ ethanol with an addition of $0.0001 \mathrm{~g}$ of BHA (2-tert-Butyl-4-hydroxyanisole) and $25 \mathrm{~mL}$ of ethylene ether and $25 \mathrm{~mL}$ of petroleum ether were then added in succession to all samples. The ether layer was collected to a $250-\mathrm{mL}$ glass flask. Subsequently, $15 \mathrm{ml}$ of ethylene ether and $15 \mathrm{~mL}$ of petroleum ether were added twice. Each time, the samples were shaken and were left overnight. The ether layer was distilled by means of aggregate for distillation of solvents. Odd fat was dried at $105{ }^{\circ} \mathrm{C}$ for $6-7 \mathrm{~h}$ to a constant weight and was then weighed.

The content of fat $(\%)$ was calculated according to the pattern: $X=[(b-a) \times 100] / c$; where: $a$-weight of flask (g), $b$-weight of flask with extracted fat $(\mathrm{g}), c$-weight of samples (g).

Fatty acids: In the case of fatty acid analysis, lipids were extracted with the use of Folch's procedure (Christie 1973). To this end, the studied material was broken up and mixed. $2 \mathrm{~g}$ of sample was homogenized for $1 \mathrm{~min}$ with $20 \mathrm{~mL}$ of methanol. Next, $40 \mathrm{~mL}$ of chloroform was added, and the course was continued for $2 \mathrm{~min}$. The prepared mixture was filtered to a $250-\mathrm{mL}$ glass cylinder. The solid residue was re-suspended in $60 \mathrm{~mL}$ of chloroform methanol $(2: 1 \mathrm{v} / \mathrm{v})$ and homogenized again for $3 \mathrm{~min}$. After filtering, the solid was washed once more with $40 \mathrm{~mL}$ of chloroform and once with $20 \mathrm{~mL}$ of methanol. The combined filtrates were transferred to the same cylinder. $0.88 \%$ sodium chloride in water (determining 1/4 volume of filtrate) was added to the total filtrate and was then shaken and left overnight. The upper layer was removed and a water-methanol mixture $(1: 1 \mathrm{v} / \mathrm{v})$ was added to the lower layer, and the 
washing procedure was repeated. The remaining layer was filtered through anhydrous sodium sulfate and was distilled by means of aggregate for distillation of solvents. The fatty acid methyl esters were prepared from total lipid with the Peisker method with chloroformmethanol-sulfuric acid (100:100:1 v/v) (Żegarska et al. 1991).

Methyl esters of fatty acids of each sample were analyzed with capillary gas chromatography with a flame-ionization detector (FID) under the following conditions:

- capillary column (dimension $30 \mathrm{~m} \times 0.25 \mu \mathrm{m}$ with a $0.32 \mathrm{~mm}$ internal diameter, liquid phase Supelcowax 10).

- temperature: flame-ionization detector $-250{ }^{\circ} \mathrm{C}$, injector $-225^{\circ} \mathrm{C}$, column $-170{ }^{\circ} \mathrm{C}$

- carrier gas-helium, flow rate $0.6 \mathrm{~mL} / \mathrm{min}$

Individual fatty acids were identified by comparing the relative retention time peaks to known standards of Supelco.

Data analysis and statistics

The data were analyzed by means of a one-way analysis of variance (ANOVA) and subsequently with Duncan's post hoc test $(\alpha=0.05)$. The statistical analysis was conducted with Microsoft Excel and Statistica v.10 (StatSoft Inc.2011, USA).

\section{Results}

The largest body weight increase (BWI $=115.4 \pm 10.7 \%$ ) was observed in the European eel females after the hormonal stimulation, in group TII, kept in saltwater for approximately 15 weeks (Table 1). The body weight in fish in the control group was found to have decreased, and the BWI value at the end of the experiment was $93.3 \pm 0.7 \%(P<0.05)$. The percentage of biochemical components of muscles and gonads was found to have changed during the period of maturation of female European eel under controlled conditions (Fig. 1). The content of fat (Fig. 1a), protein (Fig. 1b) and ash (Fig. 1d) was found to have decreased during the experiment. There was a significant difference in ash content $(P>0.05)$ between muscles in females in the initial weeks $(8.04 \pm 1.0 \%$, Group T I) and at the end (5.84 $\pm 4.2 \%$, Group T II) of the experiment (Table 1). The gonads were found to contain significantly $(P<0.05)$ less fat (decrease from $25.76 \pm 2.71$ to $15.91 \pm 4.7 \%$ ) in Group TI and Group T II, respectively (Fig. 1b; Table 1). The protein content in gonads was not statistically different at the beginning than at the end of the experiment $(P>0.05)$.

An analysis of the fatty acid content in gonads and muscles showed a statistically significant $(P<0.05)$ increase in MUFA content in both organs (Fig. 2b). A statistically significant decrease $(P<0.05)$ in $\mathrm{EPA}+\mathrm{DHA}$ (from $8.04 \pm 1.0$ to $5.84 \pm 4.2 \%$ ) (Fig. 2c) and polyene acids n-3/n-6 (from $2.02 \pm 0.28$ to $1.52 \pm 0.42 \%$ ) (Fig. 2d) was observed in muscles alone. The percentage of EPA +DHA in gonads increased $(P>0.05)$ from $10.57 \pm 1.52$ to $11.40 \pm 0.8 \%$ (Fig. 2 c). The content of saturated fatty acids in gonads or muscles (Fig. 2a) and that of polyene acids in gonads (Fig. 2d) $(P>0.05)$ did not change.

The percentage of the content of fundamental biochemical components in gonads and muscle to the whole body shows a decrease in the level of all components under study in the whole fish body $(P<0.05)$, with a simultaneous increase in their content in gonads (Fig. 3). 


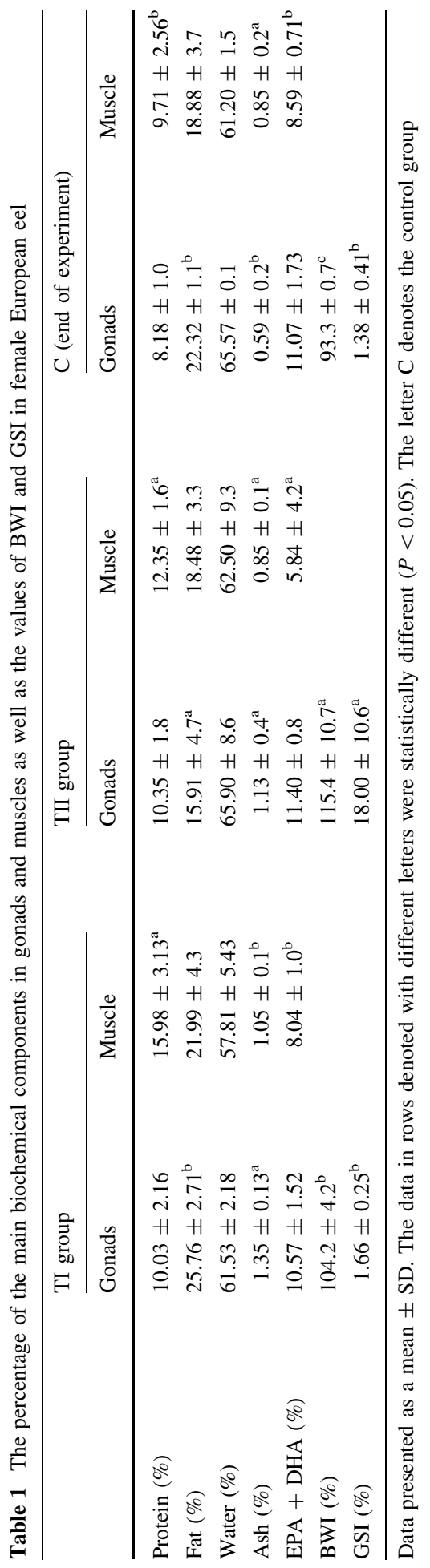



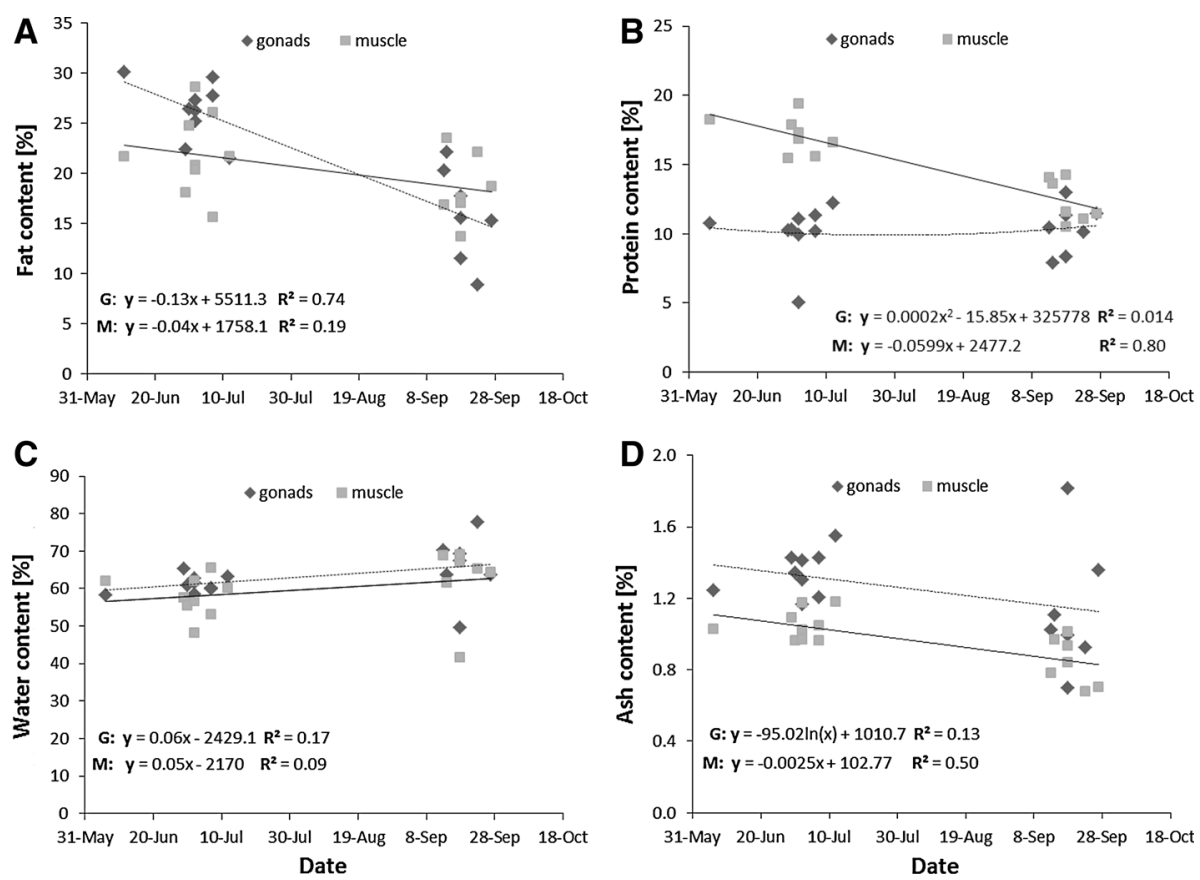

Fig. 1 Changes of the content of fat (a), protein (b), water (c) and ash (d) in gonads $(G)$ and muscles $(M)$ of female eel during the process of maturation

The GSI in the female eel was $1.66 \pm 0.25 \%$ during the initial weeks $(2-6)$ of stimulating the maturation process, whereas it grew considerably between weeks 12 and $16(P<0.05)$ and reached $18.0 \pm 10.6 \%(5.0-31.6 \%)$ on average (Fig. 4; Table 1). Size differentiation of oocytes in eel is visible from the beginning of gamete maturation (Fig. 5a). This size differentiation increases as gonads grow (Fig. 5b, c). At the same time, oocytes are at different stages of development (primary growth, pre-vitellogenic, vitellogenic), and the size differentiation increases during ovulation (Figs. 5d, 6). In group TII, the percentage of oocytes with a diameter under $0.3 \mathrm{~mm}$ decreased significantly, and the percentage of oocytes with a diameter above $0.3 \mathrm{~mm}$ increased significantly $(P<0.05)$ compared to the control group (at the experiment end) (Table 2). The average diameter of the largest oocytes in some individuals in the group (TII) was $0.83 \pm 0.08 \mathrm{~mm}$ (Figs. 5d, 6). Ovaries of the untreated females and the beginning of maturation contained a large amount of fat cells could be found among the oocytes. Fat cells disappeared among the oocytes in the ovary advantage phase. According to histological preparations (Fig. 5), there are large amount of fat tissues among the gametes in picture $\mathrm{A}$ and $\mathrm{B}$. In these pictures, the oocytes were seen in the cortical alveolus stage $(\mathrm{OD}=80-130 \mu \mathrm{m})$. In picture $\mathrm{C}$, the oocytes are between the early vitellogenic oocytes and mid-vitellogenic phase, characterizing large and small peripheral yolk granules in the cytoplasm. The number of fat cells is smaller than in previous stages.

\section{Discussion}

In order to improve the artificial reproduction of the eel, a detailed analysis of the entire ovary and gamete maturation process is required. The changes in the biochemical 

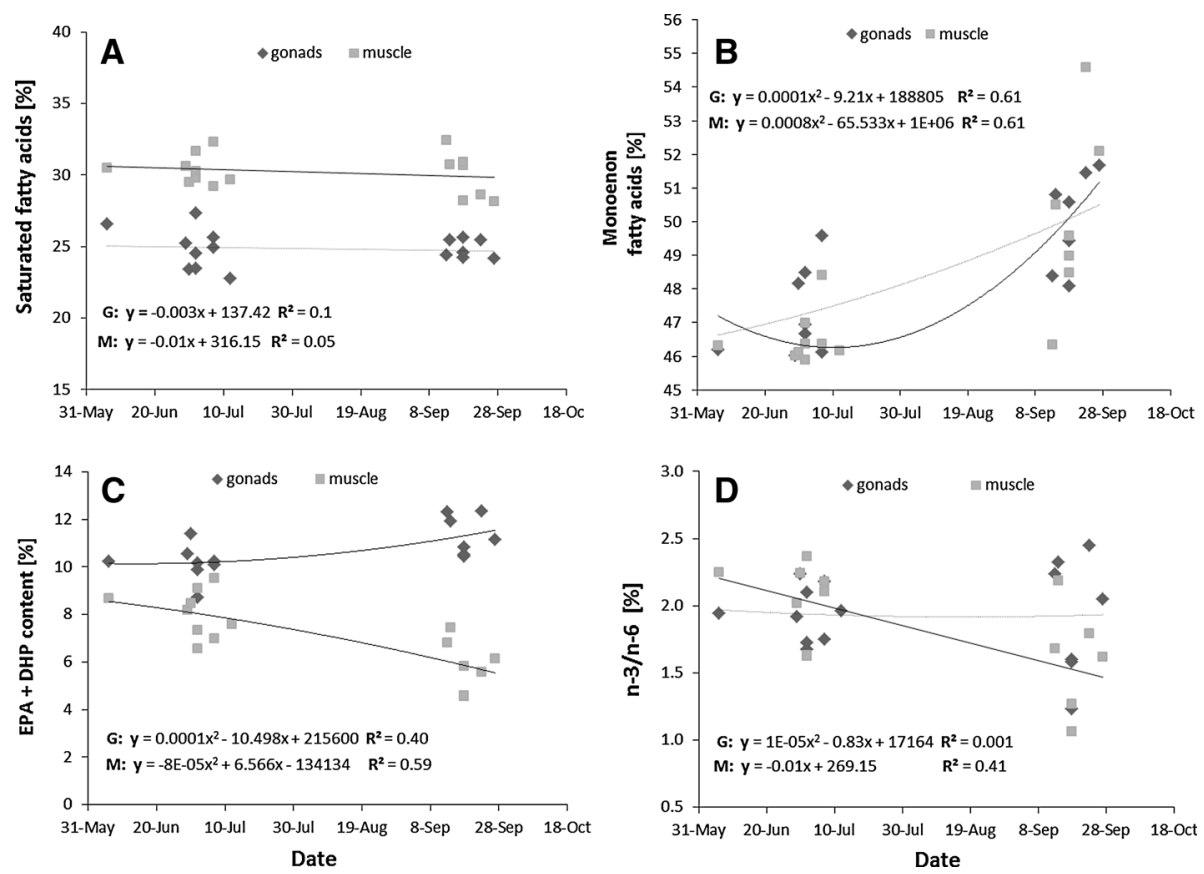

Fig. 2 Changes in the content of saturated fatty acids (a), MUFA (b), EPA and DHA (c) and n-3/n-6 (polyene) acids $(\mathbf{d})$ in gonads $(G)$ and muscles $(M)$ of female eel during the maturation process

composition of the body tissues, mainly muscles and ovaries are an indicator of the changes in the whole process. The knowledge of those changes and their dynamics will help to elucidate the process of vitellogenesis and final oocyte maturation. It will also help to understand what chemical substances are necessary for the process. This study of maturing female eels has shown a statistically significant $(P<0.05)$ decrease in fat content in gonads, but the percentage of MUFA acids increased $(P<0.05)$ and that of EDP + DHA increased slightly $(P>0.05)$. The content of fat, protein $(P>0.05)$, ash and EPA + DHA and polyene acids n-3/n-6 $(P<0.05)$ in muscles decreased. As in gonads, the content of MUFA in muscles increased significantly $(P<0.05)$. Comparing the percentages of fundamental biochemical components in gonads and muscles to the whole body reveals a surprising relationship: a decrease in the level of all the components under study (fat, protein, water and ash) in the whole fish body $(P<0.05)$ with a simultaneous increase in their content in gonads $(P<0.05)$.

Hormonal stimulation of female eel in the last phase resulted in a significant increase in the weight of the body and the gonads. In consequence, gonad weight in fish in the experimental group, compared to the control group at the start of the experiment, increased from 15 to 45 . six times. The GSI in one of the females was about $32 \%$, the same as achieved by Pedersen (2003). The mean GSI $(18.0 \pm 10.6)$ achieved in this study in female eel after 13-16 weeks of hormonal stimulation is close to the value of GSI immediately before ovulation $(20.0 \pm 11.3 \%)$ as found by other authors (e.g., van Ginneken et al. 2005a). The fish in this study had a mean BWI of $115.4 \pm 10.7 \%$ (106.1-128.5\%), which is a satisfactory result compared to that found by Pedersen (2004): $110.7 \pm 9.8 \%$. 

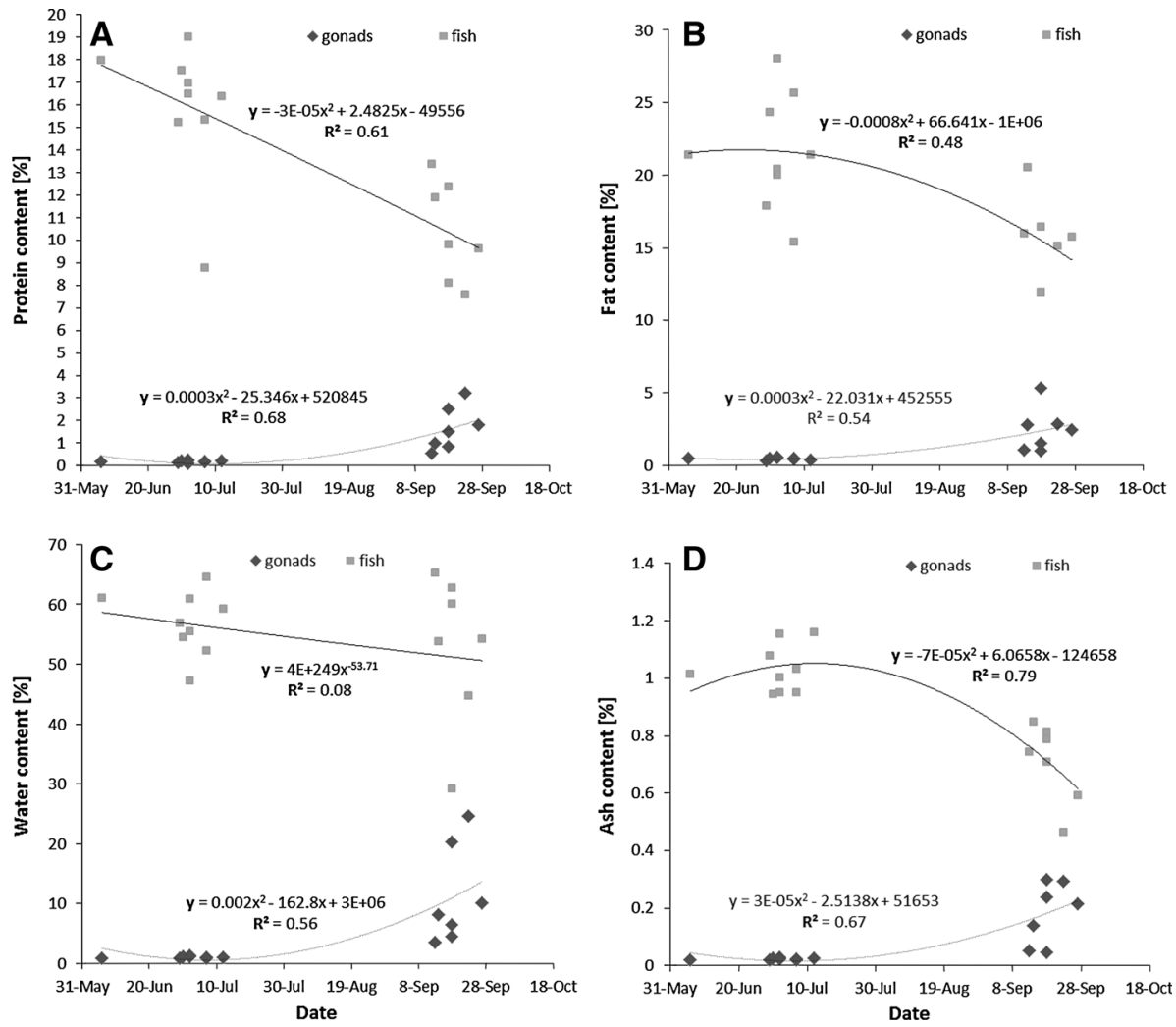

Fig. 3 Changes in the content of fat (a), protein (b), water (c) and ash (d) in gonads $(G)$ and muscles $(M)$ converted to the body weight of female eel during the maturation process

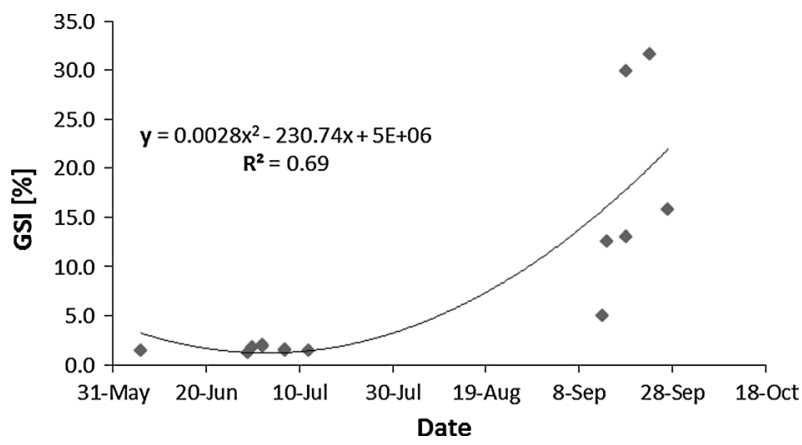

Fig. 4 Changes in the gonadosomatic index (GSI) in female European eel during the stimulated maturation process

Freshwater eel, which swim long distances to the spawning ground in saltwater, must accumulate sufficient amounts of nutrients to help them make it through the journey and develop high quality gonads. Proteins and fats are regarded as the most important nutrients responsible for successful spawning. However, according to Jędryczkowski and Fischer 


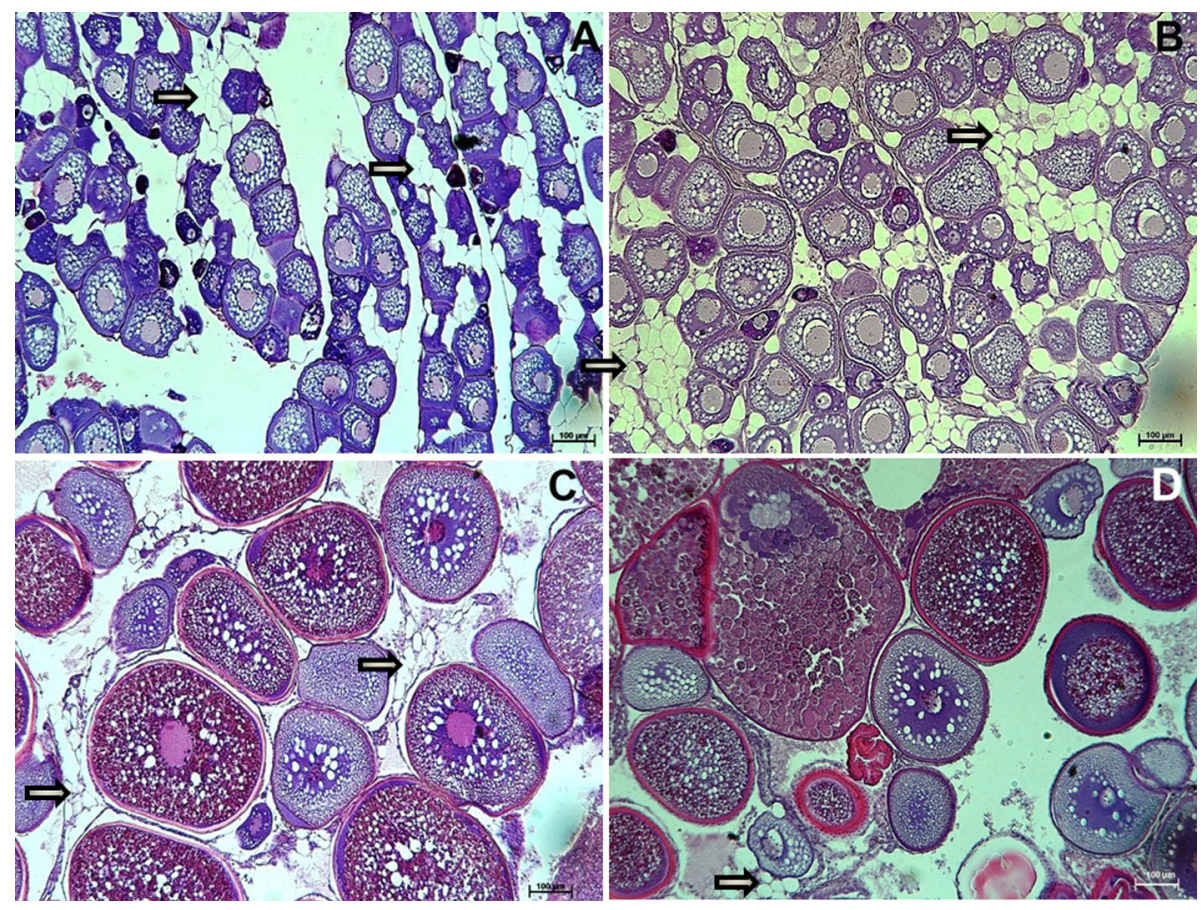

Fig. 5 Changes in the size and the stage of oocyte development in female eel at the beginning (a), in week 3 (b), in week 13 (c) and at the end of the experiment, immediately before ovulation (d). The images were taken at the same magnification (Scale bar $100 \mu \mathrm{m})$. The arrows indicate fat tissues in the ovaries

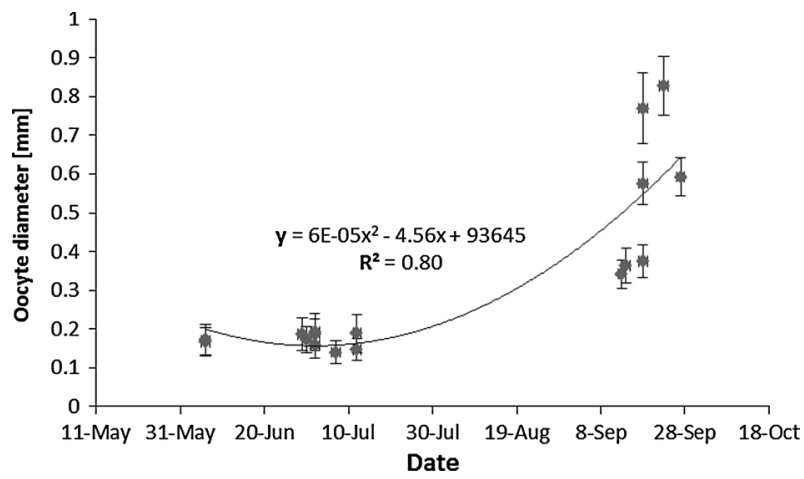

Fig. 6 The relationship between the size of oocytes with the largest diameter (mm, mean value \pm SD) and time in female European eel during the stimulated maturation process

(1973) and Clevestam et al. (2011), the fats accumulated in an eel's body are mainly responsible for successful migration. The level of fat in tissues varies from one eel species to another. For example, in Japanese eel, it ranges from 13 to $20 \%$ (Ozaki et al. 2008; Oku et al. 2009). In European eel in the Baltic region, it ranges from 20 to $38 \%$ (Clevestam et al. 2011). However, for a journey to be successful, the starting fat reserves in European 
Table 2 The percentage of oocytes in different size classes

\begin{tabular}{lllcl}
\hline Size classes & $\begin{array}{l}\text { C (beginning of } \\
\text { experiment) }\end{array}$ & $\begin{array}{l}\text { TI group } \\
(n=7)\end{array}$ & $\begin{array}{l}\text { TII group } \\
(n=7)\end{array}$ & $\begin{array}{l}\text { C (end of } \\
\text { experiment })\end{array}$ \\
\hline$<0.1 \mathrm{~mm}$ & $34.9 \pm 6.1^{\mathrm{c}}$ & $18.8 \pm 6.4^{\mathrm{b}}$ & $2.9 \pm 3.5^{\mathrm{a}}$ & $17.5 \pm 5.5^{\mathrm{b}}$ \\
$0.1-0.3 \mathrm{~mm}$ & $65.1 \pm 6.1^{\mathrm{b}}$ & $81.0 \pm 6.6^{\mathrm{b}}$ & $33.0 \pm 21.9^{\mathrm{a}}$ & $80.7 \pm 3.4^{\mathrm{b}}$ \\
$0.3-0.5 \mathrm{~mm}$ & - & $0.1 \pm 0.3^{\mathrm{b}}(n=1)$ & $43.5 \pm 11.5^{\mathrm{a}}$ & $1.8 .1 \pm 3.0^{\mathrm{b}}(n=1)$ \\
$0.5-0.7 \mathrm{~mm}$ & - & - & $14.3 \pm 17.4(n=4)$ & - \\
$>0.7 \mathrm{~mm}$ & - & - & $6.3 \pm 12.9(n=2)$ & - \\
\hline
\end{tabular}

The letter $\mathrm{C}$ denotes the control group. Data presented as a mean $\pm \mathrm{SD}$. The data in rows denoted with different letters were statistically different $(P<0.05)$. The values in brackets show the number of females in which the oocytes of a specific size class were found

eel, according to Clevestam et al. (2011), should exceed $32 \%$, otherwise the fish stand little chance of reaching the spawning ground. Such an assumption would be correct if, during its journey, an eel used fat only for swimming metabolism and the basic metabolism. However, van Ginneken et al. (2005b) and Palstra and van den Thillart (2010) estimated that about $20 \%$ of the energy consumed for swimming is produced from proteins. Considering the fact that eel are known to be much more effective swimmers than thought before (van Ginneken et al. 2005b; Palstra and van den Thillart 2010; Clevestam et al. 2011), and they save considerable amounts of energy when swimming to the spawning ground and that they swim (at least initially) at water temperatures considerably lower than those at which metabolic studies have been conducted (Aarestrup et al. 2009), it may be accepted that energy saving for swimming can be even more effective than originally assumed. It is all the more so that, as these studies have shown, eel usually make use of sea currents rather than swimming upstream. However, there is still the issue of gonads, whose weight at the end of the gamete development process is considerably larger and whose growth consumes proteins and fats. The changes in the structure of the body (muscles) and gonads (ovaries) determined in this study indicate several tendencies. As far as percentage is concerned, the protein content in hormonally stimulated females was found to have decreased from 16.0 to $12.4 \%$ and that of fat from 22.0 to $18.5 \%$ (Figs. 1, 3 ; Table 1). Conversely, the content of proteins in gonads of hormonally stimulated female eel was not found to have decreased, although the fat content decrease was substantial (from 25.8 to $15.9 \%$ ). The content of proteins in muscles in fish in the control group at the end of the study was found to have decreased significantly compared to the females in group TII (Table 1). Palstra and van den Thillart (2010) did not find any differences in the percentage biochemical composition (protein, fat, ash) in the bodies of female eel during the 6-month period of forced rest or swimming compared to the initial values. However, the fish in that study were not in the process of sexual maturation, i.e., a period of gonad growth. Therefore, there was no transfer of biochemical components from the fish bodies to their gonads. On the other hand, it may indicate that proteins and fats are consumed for the metabolic processes evenly.

Proteins and fats are important, both because of gonad growth and because they must be used as a source of energy for the basic metabolism and for fish to reach the spawning grounds (van Ginneken et al. 2005b; Clevestam et al. 2011). Reduction of the percentage of fat in ovaries, as found in this study, may be attributed to the increasing growth of GSI, from about 1.5 to over $30 \%$ in some individuals (to $18.0 \%$ on average) and the increase in the water content in the tissues under study. Such changes were not observed in male eel, which, however, were not stimulated hormonally (Palstra and van den Thillart 2010). The 
considerable decrease in the protein content in the muscles of fish in the control group at the end of this study may suggest that this component plays a very important role in providing energy for metabolism when a fish swims to the spawning ground. However, calculation of the total amounts of proteins, fats, water and ash in gonads of the European eel during the process of maturation (Fig. 3) has shown that their content decreases in the bodies of females and increases in gonads. This means that fats and proteins are transferred actively from muscles and incorporated in gonads. These findings show that the content of proteins in the whole fish body decreased more (nearly $50 \%$ ) than that of fat (a little more than $30 \%$ ), with a similar increase in both classes of substances in gonads. This may indicate that female eel use more protein than fat for swimming-related metabolism during the spawning journey and the growth of gonads. This was confirmed in the control group at the end of this experiment (Table 1). The decrease in the fat content calculated per gram in fillet and gonad tissues were measurable but, on the other hand, for the gonads, the gonadosomatic index increased from about 15 to 45 . six times. The ovaries of the untreated females contained predominantly pre-vitellogenic oocytes to the cortical alveolus stages, and ovary samples of matured eels contained oocytes from the late vitellogenic phase to overripe oocytes without fat cells among the oocytes (an effect of hormonal treatment).

The content of different groups of fatty acids during the process of female fish maturation changed. The content of saturated fatty acids remained unchanged both in gonads and in muscles (Fig. 2a). Similar findings, indicating no changes in the content of different groups of fatty acids in muscles and semen of male eels, were reported by Mazzeo et al. (2010). A slight decrease in MUFA and an increase in PUFA were reported only for the liver. It was found, in the current study, that a considerable increase in the content of MUFA (monounsaturated fatty acids) took place in both muscles and gonads during the period of female maturation (Fig. 2b). On the other hand, the combined content of EPA and DHA was found to have decreased in muscles and increased in gonads (Fig. 2c). The changes in allocation of EPA and DHA indicate considerable movement of those acids from the rest of the body to ovaries. Considering the significant growth of gonads, large amounts of EPA and DHA must have been moved selectively to the ovaries. This indicates the great significance of these acids to the process of gonad maturation in eel. However, there have been no reports on the role or precise percentage changes in fatty acid contents in female European eel during the maturation process (Mazzeo et al. 2010). Furuita et al. (2006) examined the relationship of egg quality to the content of individual substances in the Japanese eel and found high quality eggs to contain slightly less fat (40\% in high quality eggs vs. $44 \%$ in low quality eggs) and that the DHA content in eggs was positively correlated with spawn quality. On the other hand, a negative correlation was found for arachidonic acid (AA). No such studies have been conducted with European eel eggs. However, it cannot be ruled out that an increase in the total content of EPA + DHA in ovaries during the female eel maturation process is associated with oocyte maturation.

An increase in the gonad size during oocyte maturation is a normal, extensively described process. The eel has been described as a monocyclic species with one spawn during a lifetime. However, all oocytes develop simultaneously in such genera as Oncorhynchus (e.g., sockeye salmon, Pavlov et al. 2010). On the other hand, oocytes in the European eel differ in size by the initial development stage (Fig. 5a). The development phase (Fig. 5b, c) is when oocytes were found to grow and differentiate in terms of size and development level. Oocytes in different classes of size and maturity have also been found in ovaries immediately before ovulation (Fig. 5d). Such differentiation in the size and maturity of oocytes is typical of batch-spawning fish (e.g., Krejszeff et al. 2010; Targońska et al. 2011, 2012). This has been confirmed by Unuma et al. (2011) with the Japanese eel. 
As was shown by Unuma et al. (2011), the diameter of oocytes immediately before ovulation in Japanese eels which spawn in batches range from 0.8 to $1.0 \mathrm{~mm}$, although in earlier study and the current study have shown that in female European eel immediately before ovulation there are oocytes with a wide range of diameters, from about 0.01 do over $0.7 \mathrm{~mm}$. This study has shown that several (4-5) hormonal injections (group TI) bring the same results in terms of the oocyte size in female European eel as keeping female eel for 16 weeks in salt water with no hormonal stimulation (control) under the same conditions. No statistical differences $(P>0.05)$ were found in these study groups by the end of the experiment in terms of the percentage of oocytes in various size classes (Table 2). The oocyte diameters observed in this study after 5 weeks of stimulating the female fish were larger $(0.176 \pm 0.018 \mathrm{~mm})$ than those observed by other authors after 6 weeks of the experiment $(0.109 \pm 0.041 \mathrm{~mm})$ in a study examining the effect of swimming on the size of oocytes (Palstra et al. 2007). It may be concluded that hormonal treatment considerably accelerates the process of gamete maturation, which was also confirmed by a study conducted by Nowosad et al. (2014). The oocytes obtained at the end of the experiment had diameters of up to $0.853 \mathrm{~mm}$, while eggs of a similar size $(0.763-0.930 \mathrm{~mm})$ obtained by Pedersen (2003) were regarded as pre-ovulation eggs.

\section{Conclusions}

Maturation of gonads in eel is a difficult and lengthy process, which requires large amounts of energy, protein and-to a lesser extent-fats accumulated in muscles. This means that fats and proteins are transferred actively from muscles and abdominal fats and incorporated in gonads. EPA and DHA fatty acids are most probably considerably important for the maturation of female eel gonads. This is shown by changes in their allocation, which indicates the considerable movement of those acids from the rest of the body to the ovaries. More attention should probably be paid to the diet of breeding fish in which spawn is to be induced under controlled conditions, and they should be provided with the optimum amounts of EPA and DHA. When the maturation process is induced in European eel under controlled conditions, oocytes with a wide range of diameters and different stages of development can be observed throughout the whole process of maturation, which shows that this eel species spawns in batches. Hormonal treatment of female eel considerably reduces the duration of oocyte maturation.

Acknowledgments The study was financed "Innovations in finfish aquaculture with special references to reproduction," Operational Program Sustainable Development of the Fisheries Sector and Coastal Fishing Areas 2007-2013" (OR14-61724-OR1400003/09/10/11).

Open Access This article is distributed under the terms of the Creative Commons Attribution License which permits any use, distribution, and reproduction in any medium, provided the original author(s) and the source are credited.

\section{References}

Aarestrup K, Økland F, Hansen MM, Righton D, Gargan P, Castonguay M, Bernatchez L, Howey P, Sparholt H, Pedersen MI, McKinley RS (2009) Oceanic spawning migration of the European eel (Anguilla anguilla). Science 325(5948):1660

Bagiński S (1965) Technika mikroskopowa. PWN, Warszawa 
Belpaire CGJ, Goemans G, Geeraerts C, Quataert P, Parmentier K, Hagel P, De Boer J (2009) Decreasing eel stocks: survival of the fattest? Ecol Freshw Fish 18:197-214

Berg H, Nilsson S (1997) Determination of fat content in meat and meat products with NMR or SFE. Proc Euro-Food Chem IX Interlaken Switz 26:59-64

Bevacqua D, Melia P, De Leo GA, Gatto M (2011) Intra-specific scaling of natural mortality in fish: the paradigmatic case of the European eel. Oecologia 165:333-339

Christie WW (1973) The isolation of lipids from tissues. Recommended procedures. chloroform-methanol $(2: 1, \mathrm{v} / \mathrm{v})$ extraction and "Folch" wash. W: lipid analysis. Isolation, separation, identification and structural analysis of lipids. Pergamon Press Oxford, New York, pp 39-40

Clevestam PD, Ogonowski M, Sjoberg NB, Wickstrom H (2011) Too short to spawn? Implications of small body size and swimming distance on successful migration and maturation of the European eel Anguilla anguilla. J Fish Biol 78:1073-1089

Dekker W (2003) On the distribution of the European eel (Anguilla anguilla) and its Wsheries. Can J Fish Aquat Sci 60:787-799

Duriff C, Dufour S, Elie P (2006) Impact of silvering stage, age, body size and condition on reproductive potential of the European eel. Mar Ecol Prog Ser 327:171-181

Friedland KD, Miller MI, Knights B (2007) Oceanic changes in the Sargasso Sea and declines in recruitment of the European eel. ICES J Mar Scien 64:519-530

Furuita H, Unuma T, Nomura K, Tanaka H, Okuzawa K, Sugita T, Yamamoto T (2006) Lipid and fatty acid composition of eggs producing larvae with high survival rate in the Japanese eel. J Fish Biol 69:1178-1189

Jędryczkowski W, Fischer Z (1973) Preliminary report on the metabolism of the silver eel (Anguilla anguilla L.). Pol Arch Hydrob 20:507-516

Krejszeff S, Targońska K, Żarski D, Kucharczyk D (2010) Artificial reproduction of two different spawnforms of the chub. Reprod Biol 10:67-74

Kujawa R, Kucharczyk D, Mamcarz A (1999) A model system for keeping spawners of wild and domestic fish before artificial spawning. Aquacult Eng 20:85-89

Mazzeo I, Gallego V, Pérez L, Peñaranda DS, Jover M, Asturiano JF (2010) Variations in fatty acids composition in different tissues of the European eel (Anguilla anguilla L.) males during induced sexual maturation. J Appl Ichthyol 26:763-774

Müller T, Molnár T, Szabó A, Romvári R, Hancz C, Bercsényi M, Horn P (2004a) Tracking the hormonallyinduced female eel maturation by means of computer tomography. Act Vet Hung 52:235-243

Müller T, Romvári R, Bercsényi M, Hancz C, Molnár T, Szabó A, Horn P (2004b) Following the artificially induced eel maturation process by means of in vivo CT scanning. J World Aquacult Soc 35:217-224

Nowosad J, Kucharczyk D, Czarkowski TK, Kwasek K (2014) Changes in body weight and eye size in female European eel kept in fresh and salt water. Ital J Anim Sci 13:382-386

Oku T, Sugawara A, Choudhury M, Komatsu M, Yamada S, Ando S (2009) Lipid and fatty acid compositions differentiate between wild and cultured Japanese eel (Anguilla japonica). Food Chem 115:436-440

Ozaki Y, Koga H, Takahashi T, Adachi S, Yamauchi K (2008) Lipid content and fatty acid composition of muscle, liver, ovary and eggs of captive-reared and wild silver Japanese eel Anguilla japonica during artificial maturation. Fish Sci 74:362-371

Palstra AP, van den Thillart GEEJM (2010) Swimming physiology of European silver eels (Anguilla anguilla $\mathrm{L}$.): energetic costs and effects on sexual maturation and reproduction. Fish Physiol Biochem 36:297-322

Palstra AP, van Ginneken VJT, Murk AJ, van den Thillart GEEJM (2005) Are dioxin-like contaminants responsible for the eel (Anguilla anguilla) drama? Naturwissenschaften 93:145-148

Palstra AP, Curiel D, Fekkes M, de Bakker M, Székely C, van Ginneken V, van den Thillart G (2007) Swimming stimulates oocyte development in European eel. Aquaculture 270:321-332

Pavlov ED, Mikodina EV, Sedova MA, Emel'yanova NG, Markevich GN (2010) The state of gonads of resident sockeye salmon Oncorynchus nerka from the Tolmachev Reservoir. J Ichthyol 50:321-329

Pedersen BH (2003) Induced sexual maturation of the European eel Anguilla anguilla and fertilisation of the eggs. Aquaculture 224:323-338

Pedersen BH (2004) Fertilisation of eggs, rate of embryonic development and hatching following induced maturation of the European eel Anguilla anguilla. Aquaculture 237:461-473

Prigge E, Malzahn AM, Zumholz K, Hanel R (2012) Dietary effects on fatty acid composition in muscle tissue of juvenile European eel, Anguilla anguilla (L.). Helgol Mar Res 66:51-61

Targońska K, Kucharczyk D, Żarski D, Cejko B, Krejszeff S, Kupren K, Król R, Dryl K, Kowalski R, Glogowski J (2011) Artificial reproduction of wild and cultured barbel (Barbus barbus, Cyprinidae) under controlled conditions. Act Vet Hung 59:363-372 
Targońska K, Perkowski T, Żarski D, Krejszeff S, Mamcarz A, Kujawa R, Kucharczyk D (2012) Method of evaluation of wild common tench, Tinca tinca (L.), female suitability for artificial reproduction during the spawning season. Ital J Anim Sci 11:164-168

Unuma T, Hasegawa N, Sayumi Sawaguchi S, Tanaka T, Matsubara T, Nomura K, Tanaka H (2011) Fusion of lipid droplets in Japanese eel oocytes: stage classification and its use as a biomarker for induction of final oocyte maturation and ovulation. Aquaculture 322-323:142-148

van Ginneken V, Vianen G, Muusze B, Palstra A, Verschoor L, Lugten O, Onderwater M, van Schie S, Niemantsverdriet P, van Heeswijk R, Eding E, van den Thillart G (2005a) Gonad development and spawning behaviour of artificially-matured European eel (Anguilla anguilla L.). Anim Biol 55:203-218

van Ginneken V, Antonissen E, Muller UK, Booms R, Eding E, Verreth J, van den Thillart G (2005b) Eel migration to the Sargasso: remarkably high swimming efficiency and low energy costs. J Exp Biol 208:1329-1335

Vogel G (2010) Europe tries to save its eels. Science 329:505-507

Żegarska Z, Jaworski J, Borejszo Z (1991) Ocena zmodyfikowanej metody Peiskera otrzymywania estrów metylowych kwasów tłuszczowych. Act Acad Agricult Techn Olst 24:25-33 